\title{
THE ROLE OF INVESTOR SENTIMENT ON PRICING EFFECT OF PROFITABILITY RISK FACTOR IN KENYA
}

\author{
Nebat Galo Mugenda \\ PhD Student \\ School of Business \\ Jomo Kenyatta University of Agriculture \& Technology \\ P.O. BOX 62000-00200 NAIROBI, Kenya \\ E-mail: galonebat@gmail.com \\ Dhttps://orcid.org/0000-0002-7423-9503 \\ Dr. Tobias Olweny \\ Lecturer and Finance Consultant \\ School of Business \\ Jomo Kenyatta University of Agriculture \& Technology \\ P.O. BOX 62000-00200 NAIROBI, Kenya \\ E-mail: tolweny@jkuat.ac.ke \\ https://orcid.org/0000-0002-9235-8071

\section{Dr. Joshua M. Wepukhulu} \\ Lecturer and Finance Consultant \\ School of Business \\ Jomo Kenyatta University of Agriculture \& Technology \\ P.O. BOX 62000-00200 NAIROBI, Kenya \\ E-mail: matanda.joshua@jkuat.ac.ke \\ Dhttps://orcid.org/0000-0003-3417-2604
}

Received: November 01, 2021

DOI: 10.46281/ijafr.v10i1.1569
Accepted: December 30, 2021

Online Published: January 26, 2022

URL: https://doi.org/10.46281/ijafr.v10i1.1569

\begin{abstract}
Emerging stock markets are characterized by strong investor sentiment and rapid fluctuations in returns. However, the role of investor sentiment on asset pricing has not been explored in these markets. This study sought to establish if the effect of the profitability risk factor on stock returns would vary with the level of investor sentiment at the Kenyan equity market. A quantitative causal time-series design was adopted to analyze the cause-effect relationship among the study variables. The study utilized monthly equity return data on 60 firms listed at the Nairobi Securities Exchange (NSE) from 2011 to 2019. Test portfolios were constructed following the Fama-French five-factor model framework. Auto-Regressive Distributed Lag (ARDL) and Vector Error Correction (VEC) estimation techniques show that profitability risk factor is a significant predictor of stock returns at a 5\% level. Overall, though not consistent with valuation theory, the coefficient on profitability risk factor is negative, implying a high exposure to profitability risk results in low returns. Further, adding sentiment variables to the main effects model would enhance the significance of the profitability risk factor at the NSE. The evidence
\end{abstract}


presented contributes to establishing investment strategies, estimating the required rate of return and assessing portfolio performance of collective investments.

Keywords: Profitability Risk Factor, Stock Returns, Investor Sentiment, Auto-Regressive Distributed Lag, Vector Error Correction Model.

JEL Classification Codes: C32, G11, G12, G14, G41.

\section{INTRODUCTION}

The question as to why returns vary across stocks continues to draw attention among academics and practitioners alike (Taha \& Elgiziry, 2016). A section of asset pricing studies shows that variation in stock returns can be explained by exposure to macroeconomic factors and firm-level fundamental characteristics that proxy for systematic risk (Karp \& Vuuren, 2017). Other studies underscore the role of market imperfections in the study of equilibrium models (Li \& Zhang, 2010; Chae \& Yang, 2016). Whereas traditional finance theorists assume rational investors, behaviorists maintain that investors are not fully rational and that stock returns may be affected by irrational investor behavior (Schmeling \& Shiller, 2009). However, it is not established how investor irrationality would influence the relationship between profitability risk factors and stock returns in Kenya.

The theory of market efficiency supports the argument that firms should provide returns to investors in terms of risk exposure. Consequently, profitable firms should yield higher returns than less profitable firms since they are deemed riskier. According to the dividend valuation model, high expected future earnings would warrant higher expected returns after holding constant the net book value of equity, equity's market value, and growth in total assets (Fama \& French, 2008). These profits are the reward for growth and innovation, which exposes entrepreneurs to greater risk, thus warranting a higher required rate of return (Fama \& French, 2008). Novy-Marx (2013) and Mosoeu and Kodongo (2017) also support the existence of profitability factors across selected emerging markets. However, contrasting results by Faff (2004) show that profitability does not add much explanatory power to asset pricing in Brazil, particularly when the model does not control for trading frictions. Research documenting the effect of firm profitability as a determinant of expected stock returns in Kenya is scanty, thus justifying the current study.

The Kenyan equity market is gaining extreme importance as an avenue for new opportunities for global diversification. As an emerging market, the NSE poses a peculiar market to investigate because it is the largest, best regulated and most advanced in East and Central Africa, with higher relative trade volumes (Coffie \& Chukwulobelu, 2013). The rationale for studying the Kenyan equity market lies in the inherent nature of the market characterized by higher volatility, thin trading, illiquidity, mispricing of assets, and non-normally distributed equity returns (Coffie \& Chukwulobelu, 2013). Some theorists suggest that global capital markets are significantly integrated and propose using a global or international asset pricing model to estimate return. However, Ayrapetova and Larionova (2016) maintain that applying the global version of the asset pricing model in emerging capital markets has proved impractical and controversial since these markets are highly segmented and have countryspecific barriers. Hence, investors looking to diversify their portfolios globally find it difficult to estimate the cost of equity for their investment decisions using asset pricing models that have been tested in developed markets. A renewed interest has since developed among practitioners and academics in searching for context-specific models for the portfolio construction process. The attention has come about because of the largely positive and sometimes very large negative returns realized in these markets.

Evidence exists that firm-level fundamental variables may proxy systematic risk (Karp \& Vuuren, 2017) and that market conditions may influence stock returns (Chae \& Yang, 2016). However, there are gaps in the literature concerning the selection of predictor variables and methodological considerations. The risk-return relationship has been investigated extensively across global markets over a wide spectrum of sample periods. However, research findings differ due to the diversity of context focus, variable selection, and methodology adopted. Like other emerging markets, the Kenyan equity 
market is characterized by information inefficiencies and segmentation causing significant constraints to effective diversification (Hiremath, 2014). A survey conducted by Alexander Forbes Consulting Actuaries Schemes shows that returns on the Kenyan equity market are influenced by investor sentiment, which may oscillate between bullish or bearish cycles. There is, however, no existing study to explain the risk-return relationship adjusting for realities in emerging markets. This study sought to bridge the gap in asset pricing literature by investigating the role of investor sentiment in the relationship between profitability risk and stock returns in Kenya, controlling for premium on market, size, value and asset growth risk factors.

This study provides insightful information to various market players, which could enhance their understanding of asset pricing dynamics. Asset pricing models are used to guide individual and institutional investors in decisions involving security selection which could affect their investment choices and profit opportunities. It also provides useful information that could serve as the basis for advising investors on how to formulate financial goals and create strategies to achieve the goals considering financial risks. The information on asset pricing is very useful for guiding the capital markets regulator in formulating policy for effective monitoring of the markets to protect market players.

\section{EMPIRICAL LITERATURE}

\section{Profitability Risk Factor and Stock Returns}

The question as to whether profitability is a priced factor has been at the center stage of recent studies on asset pricing. Kubota and Takehara (2018) tested the validity of the FF5F model in Borsa Istanbul using excess returns of 14 portfolios sorted based on firm size. The sample comprised all non-financial firms trading on Borsa Istanbul, according to the approach suggested by Fama and French (1992). The study employed 132 monthly data between July 2005 to June 2016 as the sample period with a sample size range of between 174 and 281 firms. Firm Profitability was measured as EBIT to book value of equity ratio (Fama \& French, 2015). The profitability factor was computed as the return difference between robust and weak profitability portfolios (RMW). Results of the analysis showed a higher premium on market portfolios over the profitability factor, implying that maximum return premium can be obtained from the market portfolio.

Mosoeu and Kodongo (2017) also examined the association between firm profitability and stock returns in selected emerging markets using the FF5F model. The study utilized weekly stock return data between January 2010 and December 2016. Generalized Method of Moments (GMM) was used to run regressions and GRS tests to measure how well the model fits data. The results from RMW regressions showed that the profitability factor is a statistically significant-priced factor across all countries examined except South Africa and Singapore. The intercepts for these countries were positive, with an average standard error of 3.08 from zero. Fama and French (2016) observed similar results with a significant profitability factor and standard error of 3.95 from zero in the same context. Further evidence of the profitability-return relationship is reported in Novy-Marx (2013).

Basiewicz and Auret (2010) compared the performance of a three-factor model developed by Chen, Novy-Marx, and Zhang (2011) against that of Fama and French (1993) in South Africa. The former model augments the CAPM market factor with profitability and investment. The period of study spanned 9 years, from 2002 to 2011. The authors argue that the profitability variable, ROE, explains the variance of returns since shocks to profitability are positively related to contemporary shocks to returns, an aspect not present in the FF3F model. The ROE factor was derived by dividing the quarterly net profit (NP) with one-quarter-lagged book equity (BE). The book-equity was defined as the shareholders' equity plus deferred taxes reported in the financial statements and investment tax credit less book value of the preferred stock. The results obtained a negative coefficient for ROE, which implies that companies were less profitable during the period of study, especially those in the high profitability ratio portfolios. This indicates a potential for lower returns because, quite intuitively, companies that are expected to be relatively less profitable will most likely deliver lower returns than their profitable counterparts. 
Building on evidence by Novy-Marx (2013) and Aharoni et al. (2013), Fama and French (2015) examined the explanatory power of a five-factor model using US data. The FF5F model extends the three-factor model that accounts for the effect of firm profitability and investment on expected returns. The profitability factor was measured as the spread of returns on a portfolio of stocks with high operating profitability and low operating profitability. The study used 606 monthly observations for data from 1963 to 2013. Return on one-month treasury was used to estimate the risk-free rate of interest. The portfolios of portfolios were constructed based on the Fama-French (1993) approach, using a 2x3 annual sorting procedure. The results showed a negative correlation between profitability factor, market and size factor, providing important information regarding potential benefits from portfolios that diversify exposures across these factors.

A comparative study on the pricing effect of Fama-French anomalies on excess returns of sizeprofitability stocks in Nordic markets was investigated. The theoretical intuition in variable conceptualization was connected to the DDM model. The study employed monthly price data and total return downloads from Thomson Datastream over a period spanning from 1999 to 2015. The pricing factors were constructed following the description in Fama and French (2015) framework on a 4x4 sorting criterion in order to keep portfolios well diversified. The dependent variables were the excess returns on 48 sample portfolios. Monthly returns on stocks, market premium, and the risk-free interest rate were calculated as mean returns from the asset's total return indices. Operating profit was computed by dividing operating income by the book value of equity. The GRS statistics and model regression intercepts were analyzed to measure the performance of each model. The intercepts in the FF5F model were mostly jointly indistinguishable from zero on the GRS test, implying that the FF5F model was closest to a complete description of average returns. Overall, the study observed significant loadings of RMW on all, but size-profitability sorted portfolios.

Faff (2004) investigated whether profitability is priced and partially explains the mean return of stocks in the Brazilian stock market under the model framework developed by Fama and French (2015). The study employed both time series and cross-sectional regression on sample data spanning 1st June 1997 to $30^{\text {th }}$ June 2014. The study included data on both active and inactive stocks in the Brazilian capital market to minimize survivor bias error. Financial firms were excluded from analysis following the argument by Fama and French (1992) that the B/M ratio for financial firms is influenced by their degree of leverage. Also excluded were firms with negative equity. For purposes of portfolio sorting, profitability was calculated as earnings before interest and tax divided by the operational assets. Models were formed from a combination of risk factors. The study further examined if the method of factor premium construction has implications on asset pricing. The study found that regardless of how factors are constructed, models with no HML have the highest GRS statistic and absolute intercept, which implies that HML is important in explaining returns. Additionally, profitability does not add much asset pricing explanatory power in Brazil, possibly because the model does not control trading frictions, a common feature in developing countries. Against this background, the current study sought to establish the pricing effect of a profitability risk factor at the NSE controlling for investor sentiment.

Based on an exposition of the literature, it was hypothesized that:

\section{Hol: The profitability risk factor does not significantly explain stock returns at the NSE.}

\section{Investor Sentiment and Stock Returns}

Chuang et al. (2010) employed a generalized autoregressive conditional heteroskedasticity in mean (GARCH-M) model to study the impact of the movement in investor sentiment on stock returns in Taiwan. The sample period for the study spanned 14 years from 1990 to 2004, with 779 weekly observations. The study was premised on the hypothesis that trading volume change represents movement in investor sentiment. The results show that contemporary sentiment proxy has better explanatory power on excess return and conditional volatility. Supporting the same proposition, Baker and Wurgler (2007) concluded that a change in trading volume could reflect some degree of investors' expectations in the Taiwan stock market. 
Bathia and Bredin (2012) examined whether incorporating investor sentiment, as conditioning information, can help to capture the predictive ability of firm size, value, liquidity and momentum in explaining risk-adjusted returns of individual stocks at the New York Stock Exchange (NYSE). The study incorporated different investor sentiment measures in different asset pricing models to determine if they enhanced the performance of these models. The study employed two-pass time-series regression of excess monthly returns on individual stocks from 1981 to 2010. Results showed that sentiment augmented asset pricing models often capture the predictive power of firm fundamental attributes. Furthermore, the study found that the value and momentum effects are effectively captured in the sentiment augmented conditional version of the Fama and French (1993) three-factor model.

The effect of investor sentiment on stock returns was highlighted by Tran and Nguyen (2013) in the Norwegian and Vietnamese markets from 1991 to 2013. They employed Brown and Cliff's (2005) ADR Index and Consumer Confidence Index as additional components to improve the predictive power of the sentiment index. The study concluded that the effect of sentiment on stock returns is more pronounced in small, volatile, value stocks that do not pay dividends. The results further revealed a negative association between sentiment and stock returns, particularly for firms with negative returns in Norway and volatile ones in Vietnam. However, these results are consistent with the findings in Baker and Wurgler (2007), in which study the sentiment effect was found to be more profound in stocks that are not easy to value and arbitrage.

Dalika and Seetharam (2015) investigated the impact of investor sentiment on stock returns in the South African market from 1999 to 2009. The study was premised on the assumptions that mispricing is caused by both an uninformed demand shock and limits to arbitrage. The authors adopted the methodology of Baker and Stein (2004) to develop the sentiment index. The sentiment series was estimated as the first principal component in the orthogonalized sentiment proxies. A set of portfolios was formed according to Fama and French's (1993) methodology. The results indicated that investor sentiment strongly impacts share returns in the South African market. During low sentiment periods, subsequent returns were relatively high, especially among low market cap, highly volatile, growth and start-up firms. These patterns, however, were observed to reverse when sentiment was high.

From the analysis of prior literature, we formulated the hypothesis that:

\section{Ho2: The effect of profitability risk on stock returns independent of the NSE's investor sentiment.}

\section{Research Gaps}

Most studies on asset pricing are confined to global markets (Hearn \& Piesse, 2009). In many African equity markets, the return generating process is not well established, making it difficult to identify components for risk premia due to a lack of reliable historical data (Basiewicz \& Auret, 2010). A study of this nature would therefore bridge an important contextual gap. Past studies have often neglected the role of different states of investor sentiment in explaining risk-adjusted returns (Lind \& Sparre, 2016). However, the current study considers that asset pricing in emerging markets is more likely to be influenced by either category of investors. Further, a significant contribution of this article is in the use of robust estimation methods in the analysis of associations.

\section{DATA AND METHODOLOGY}

This study was anchored on a positivist philosophical perspective whereby the established theoretical linkage between profitability risk factor and variation in cross-section of stock returns was used to develop the hypothesis tested and validated against empirical observations. A causal research design was employed to explain the cause-effect relationship between profitability risk factors and stock returns in Kenya. A time-series study design was also adopted to analyze patterns and identify short-term and long-term trends in the data. The study utilized secondary data obtained from audited annual company reports, reports and publications of the central bank of Kenya, the Capital Markets Authority, the NSE annual investor handbook and daily equity price lists. The availability informed the analysis period from January 2011 to December 2019 of data on variables. A census of firms listed at the NSE was conducted 
but the final sample frame comprised 60 firms that met the selection criteria commonly used in asset pricing literature.

\section{Portfolio and Factor Construction}

At the end of December each year, stocks were distributed into two size groups and independently allocated to two groups of market valuation, asset growth and operating profitability using median breakpoints. Profitability effect (OPROF) was measured as the excess of operating income over a firm's operating expenses at the end of December in year t-1. Size (SIZE) was measured as the market capitalization of equity stock at the end of December in year t-1. The value effect (VALUE) was computed as the book to market capitalization ratio at the end of December in year t- 1 . Asset growth (ASTG) proxy for firm investment was computed as an annual percentage change in total assets at the end of year t-1 (Fama and French, 2015). The intersection of the independent 2x2 sorting yielded 12 portfolios. Investor Sentiment (SENT) was measured as the bull-bear spread, obtained by subtracting the proportion of stocks that closed lower from the proportion that closed higher than their previous period's closing prices. A positive (negative) spread implies a bullish (bearish) trend in the market, while a zero difference is an indicator of a market correction (Brown \& Cliff, 2005; Dash \& Mahakud, 2013). The market risk factor (MKT) is the excess expected return on the diversified risky market portfolio over the Kenyan T-bill rate with a duration same as that of the market portfolio (Berk \& Van Binsbergen, 2016).

\section{Correlation Analysis}

Table 1. Correlation Analysis (Pearson Corr. Coef)

\begin{tabular}{|l|l|l|l|l|l|l|}
\hline & MKT & SIZE & VALUE & OPROF & ASTG & OPROF*SE \\
\hline MKT & $\mathbf{1 . 0 0 0 0}$ & & & & & \\
\hline SIZE & $\mathbf{- 0 . 2 3 1 8} * *$ & $\mathbf{1 . 0 0 0 0}$ & & & & \\
\hline & {$[-2.4539]$} & ---- & & & & \\
\hline & 0.0158 & ---- & & & & \\
\hline VALUE & $\mathbf{0 . 0 0 3 7}$ & $\mathbf{- 0 . 1 2 0 6}$ & $\mathbf{1 . 0 0 0 0}$ & & & \\
\hline & {$[0.0382]$} & {$[-1.2510]$} & ---- & & & \\
\hline & 0.9696 & 0.2137 & ---- & & & \\
\hline OPROF & $\mathbf{0 . 0 6 2 7}$ & $\mathbf{0 . 1 6 9 7}$ & $\mathbf{0 . 2 4 4 6} * *$ & $\mathbf{1 . 0 0 0 0}$ & & \\
\hline & {$[0.6463]$} & {$[1.7726]$} & {$[2.5972]$} & ----- & & \\
\hline & 0.5195 & 0.0792 & 0.0107 & ---- & & \\
\hline ASTON & $\mathbf{- 0 . 0 9 4 2}$ & $\mathbf{- 0 . 0 4 3 1}$ & $\mathbf{0 . 0 1 9 6}$ & $\mathbf{- 0 . 2 4 5 3} * *$ & $\mathbf{1 . 0 0 0 0}$ & \\
\hline & {$[-0.9741]$} & {$[-0.4442]$} & {$[0.2021]$} & {$[-2.6046]$} & ----- & \\
\hline & 0.3322 & 0.6578 & 0.8402 & 0.0105 & ----- & \\
\hline SENT & $\mathbf{0 . 6 5 8 2} *$ & $\mathbf{- 0 . 0 3 7 7}$ & $\mathbf{- 0 . 0 4 0 2}$ & $\mathbf{- 0 . 0 0 1 3}$ & $\mathbf{- 0 . 0 9 9 1}$ & $\mathbf{1 . 0 0 0 0}$ \\
\hline & {$[9.0005]$} & {$[-0.3881]$} & {$[-0.4147]$} & {$[-0.0131]$} & {$[-1.0254]$} & ----- \\
\hline & 0.0000 & 0.6988 & 0.6792 & 0.9896 & 0.3075 & ----- \\
\hline OPROF*SENT & 0.0361 & 0.0831 & $0.2188^{* *}$ & 0.1893 & 0.0507 & -0.0001 \\
\hline & {$[0.3718]$} & {$[0.8584]$} & {$[2.3083]$} & {$[1.9852]$} & {$[0.5231]$} & {$[-0.0014]$} \\
\hline & 0.7108 & 0.3926 & 0.0229 & 0.0497 & 0.6020 & 0.9989 \\
\hline
\end{tabular}

Table 1 displays a pair-wise correlation matrix of main effects predictor variables. Underneath each coefficient are the t-values in square brackets (based on the Newey-West adjusted standard errors) and $p$-values at a 5\% level of significance. The table generally shows the low and insignificant correlation among the main effects variables. There was however significant but less low correlation between MKT and SIZE $(\mathrm{r}=-0.2318, p<0.05)$, OPROF and VALUE $(\mathrm{r}=0.2446, p<0.05)$ and OPROF and ASTG $(\mathrm{r}=-0.2453, p<0.05)$. The table further shows that market risk premium $(\mathrm{MKT})$ and 
sentiment (SENT) are moderately positively correlated $(\mathrm{r}=0.6582)$, implying that market risk and investor sentiment variables have a positive co-movement at the Kenyan equity market. In general, the low-to-moderate correlations help mitigate any potential multicollinearity issues that could impact our empirical specifications.

\section{Times Series Assumptions}

\section{Stationarity and Cointegration}

This study utilized the ADF and P-P unit root tests to examine the stationarity of the variables at a 5\% level of significance. The unit root test results are shown in Tables $2 \mathrm{a}$ and $2 \mathrm{~b}$.

Table 2a. Unit Root Test for Predictor Variables

\begin{tabular}{|l|l|l|l|l|l|l|}
\hline Series & $\begin{array}{l}\text { Augmented } \\
\text { Dickey-Fuller } \\
\text { t-Stat }\end{array}$ & $\begin{array}{l}\text { MacKinnon } \\
\text { Crit. (5\%) }\end{array}$ & p-Value & $\begin{array}{l}\text { Phillips- } \\
\text { Perron } \\
\text { Adj. t-Stat } \\
\text { (At Level) }\end{array}$ & $\begin{array}{l}\text { Test Crit. } \\
\text { Values. } \\
(5 \%)\end{array}$ & $\begin{array}{l}\text { p- } \\
\text { Value }\end{array}$ \\
\hline MKT & -9.5690 & -2.8887 & 0.0000 & -9.6643 & -2.8887 & 0.0000 \\
\hline SIZE & -9.5690 & -2.8895 & 0.0126 & -11.2721 & -2.8887 & 0.0000 \\
\hline VALUE & -3.4143 & -2.8895 & 0.0126 & -11.2721 & -2.8895 & 0.0000 \\
\hline OF & -11.2252 & -2.8887 & 0.0000 & -11.2309 & -2.8887 & 0.0000 \\
\hline ASTON & -11.0085 & -2.8887 & 0.0000 & -10.9907 & -2.8887 & 0.0000 \\
\hline SENT & -5.0304 & -2.8889 & 0.0000 & -8.3948 & -2.8887 & 0.0000 \\
\hline OPROF*SENT & -11.7842 & -2.8887 & 0.0000 & -11.7392 & -2.8887 & 0.0000 \\
\hline
\end{tabular}

Table 2b. Unit Root Test for Dependent Variables

\begin{tabular}{|l|l|l|l|l|l|l|}
\hline EX-RET & ADF Fisher & MacKinnon & $p$-Value & Phillips- & Test Crit. & $p$-Value \\
\hline Port. 1 & -8.5160 & -2.8887 & 0.0000 & -8.8092 & -2.8887 & 0.0000 \\
\hline 2 & -4.0849 & -2.8892 & 0.0016 & -9.4303 & -2.8887 & 0.0000 \\
\hline 3 & -5.5349 & -2.8889 & 0.0000 & -9.2893 & -2.8887 & 0.0000 \\
\hline 4 & $\mathbf{- 9 . 4 9 2 4 *}$ & $\mathbf{- 2 . 8 8 9 8}$ & $\mathbf{0 . 0 0 0 0}$ & -8.3183 & -2.8887 & 0.0000 \\
\hline 5 & -4.1382 & -2.8892 & 0.0013 & -10.5892 & -2.8887 & 0.0000 \\
\hline 6 & $\mathbf{- 1 1 . 1 9 1 7} *$ & $\mathbf{- 2 . 8 8 9 8}$ & $\mathbf{0 . 0 0 0 0}$ & -30.7178 & -2.8889 & 0.0001 \\
\hline 7 & -10.3239 & -2.8887 & 0.0000 & -10.4455 & -2.8887 & 0.0000 \\
\hline 8 & -5.4335 & -2.8889 & 0.0000 & -10.2600 & -2.8887 & 0.0000 \\
\hline 9 & -5.3925 & -2.8889 & 0.0000 & -9.8483 & -2.8887 & 0.0000 \\
\hline 10 & -11.7273 & -2.8887 & 0.0000 & -11.8159 & -2.8887 & 0.0000 \\
\hline 11 & -5.6378 & -2.8889 & 0.0000 & -9.5862 & -2.8887 & 0.0000 \\
\hline 12 & -4.4265 & -2.8892 & 0.0005 & -10.9756 & -2.8887 & 0.0000 \\
\hline
\end{tabular}

*Denotes variable stationary at $1^{\text {st }}$ difference

From the results in Table 2(a), the null hypothesis of the unit root was not supported for all predictor variables and interacting terms at the level. Hence all the predictor variables and interacting terms were stationary at level. Results in Table 2(b) show that excess return on portfolio $4(\mathrm{t}=-9.4924$, $p$-value $=0.0000)$ and portfolio $6(\mathrm{t}=-11.1917, p$-value $=0.0000)$ are stationary at first difference on the ADF test while the rest of the series are stationary at level on both tests. Thus, the dependent variables display a mix of the $I(0)$ and $I(1)$ series. Narayan (2005) recommends the performance of bounds test of co-integration in circumstances where variables display a combination of $I(0)$ and $I(1)$ series. 
Table 2c. F-Bounds Co-integration Test

\begin{tabular}{|l|l|l|l|l|l|}
\hline Series & F-Stat & Sig. & Lower & Upper Bound $I(1)$ & Null Hyp. \\
\hline Port 1. & 97.58107 & $5 \%$ & 2.45 & 3.61 & Reject \\
\hline 2 & 49.93288 & $5 \%$ & 2.45 & 3.61 & Reject \\
\hline 3 & 54.40527 & $5 \%$ & 2.45 & 3.61 & Reject \\
\hline 4 & 7.528333 & $5 \%$ & 2.45 & 3.61 & Reject \\
\hline 5 & 64.05054 & $5 \%$ & 2.45 & 3.61 & Reject \\
\hline 6 & 89.65671 & $5 \%$ & 2.45 & 3.61 & Reject \\
\hline 7 & 101.7796 & $5 \%$ & 2.45 & 3.61 & Reject \\
\hline 8 & 67.39544 & $5 \%$ & 2.45 & 3.61 & Reject \\
\hline 9 & 257.4762 & $5 \%$ & 2.45 & 3.61 & Reject \\
\hline 10 & 83.94939 & $5 \%$ & 2.45 & 3.61 & Reject \\
\hline 11 & 107.9854 & $5 \%$ & 2.45 & 3.61 & Reject \\
\hline 12 & 135.8706 & $5 \%$ & 2.45 & 3.61 & Reject \\
\hline
\end{tabular}

Results in Table 2c show that all regressions on the twelve portfolios have F-statistic greater than the upper critical bounds value. Consequently, the null hypothesis of no co-integration was rejected, and hence it was concluded that there is co-integration. From the above analysis, we estimated both the ARDL and VECM models for short-run and long-run relationships among the variables.

\section{Lag Length Selection}

The need to select an optimal number of lags for each model used in time series analysis is premised on the assumption that regressand will tend to respond to regressor variables with a lapse of time (Pesaran, Shin, \& Smith, 2001). Adding lagged terms can eliminate the influence of uncontrollable factors, thereby increasing the credibility of the regression results. However, including too many lagged values in a model can consume degrees of freedom and might introduce the likelihood of multicollinearity. In this study, optimal lag length selection was based on the lower value of Akaike information criterion (AIC), Schwarz information criterion (SIC) and Hannan-Quinn (HQ) information criterion computations. Hence, the appropriate lag is one according to AIC, SIC, and HQ criteria.

\section{Residual Diagnostics}

Multicollinearity assumption was assessed using the Variance Inflation Factor (VIF). All variables yielded VIF less than 10 suggesting the absence of multicollinearity as recommended in Field (2009). The null hypothesis of homoscedastic data was supported in all regressions on test portfolios using the Breusch-Pagan Godfrey test and White's General Heteroscedasticity test at a 5\% level of significance. Autocorrelation assumption was tested using Breusch-Godfrey (BG) Lagrange Multiplier since the models contain non-stochastic lagged values of the regressand (Gujarati, 2003). The BG LM test supported the null hypothesis of no serial correlation, implying that the models were properly specified and that the OLS standard errors and statistics were reliable and consistent. Normality of residuals was tested using histogram and normal probability Q-Q plots following recommendations by (Nguyen, 2016).

\section{Model Specification}

\section{The ARDL short-run Main Effects model}

The main effects model was used to check the amount of variation in stock returns accounted for by profitability risk factor without influence of sentiment. 


$$
\begin{aligned}
\Delta\left(R_{j}-r_{f}\right)_{t} & =\alpha_{0}+\sum_{i}^{p} \delta_{\mathrm{i}} \Delta\left(R_{j}-r_{f}\right)_{t-i}+\sum_{i}^{q_{1}} \beta_{\mathrm{i}} \Delta(M K T)_{t-i}+\sum_{i}^{q_{2}} r_{\mathrm{i}} \Delta(\text { OPROF })_{t-i}+\text { Controls }_{t-i} \\
& +e_{1 t}
\end{aligned}
$$

The Error Correction Main Effects Model Representation

$$
\begin{aligned}
\Delta\left(R_{j}-r_{f}\right)_{t}= & \alpha_{0}+\sum_{i}^{p} \delta_{i} \Delta\left(R_{j}-r_{f}\right)_{t-i}+\sum_{i}^{q_{1}} \beta_{i} \Delta(M K T)_{t-i}+\sum_{i}^{q_{2}} r_{i} \Delta(\text { OPROF })_{t-i}+\text { Controls }_{t-i} \\
& +\varphi E C T_{t-1}+e_{2 t}
\end{aligned}
$$

The ARDL short-run Interaction Model

$$
\begin{aligned}
\Delta\left(R_{j}-r_{f}\right)_{t}= & \alpha_{0}+\sum_{i=1}^{n} \delta_{\mathrm{i}} \Delta\left(R_{j}-r_{f}\right)_{t-i}+\sum_{i=0}^{n} \beta_{\mathrm{i}} \Delta(M K T)_{t-i}+\sum_{i=0}^{n} r_{\mathrm{i}} \Delta(\text { OPROF })_{t-i}+\text { controls }_{t-i} \\
& +\sum_{i=0}^{n} \xi_{\mathrm{i}} \Delta(S E N T)_{t-i}+\sum_{i=0}^{n} \gamma_{\mathrm{i}} \Delta(\text { OPROF } * S E N T)_{t-i}+e_{3 t}
\end{aligned}
$$

The Error Correction Interaction Model Representation

Where:

$$
\begin{aligned}
\Delta\left(R_{j}-r_{f}\right)_{t}=\alpha_{0}+\sum_{i=1}^{n} \delta_{\mathrm{i}} \Delta\left(R_{j}-r_{f}\right)_{t-i}+\sum_{i=0}^{n} \beta_{\mathrm{i}} \Delta(M K T)_{t-i}+\sum_{i=0}^{n} r_{\mathrm{i}} \Delta(O P R O F)_{t-i} \\
+ \text { controls }_{t-i} \\
\quad+\sum_{i=0}^{n} \xi_{\mathrm{i}} \Delta(S E N T)_{t-i}+\sum_{i=0}^{n} \gamma_{\mathrm{i}} \Delta(O P R O F * S E N T)_{t-i}+\varphi E C T_{t-1}+e_{3 t}
\end{aligned}
$$

Note: The short-run model terms go with difference operator

$R_{j}-r_{f}$ : Excess return on portfolio $j$

$\alpha_{0}$ : Intercept of the model. If the predictors in a model capture adequately stock returns, $\alpha_{0}$ should be indistinguishable from zero

$\delta_{i}$ : The coefficient loading for the lagged value of the dependent variable

$\beta_{i}$ : The coefficient loading for the market risk factor (MKT)

$r_{\mathrm{i}}$ : The coefficient loading for the profitability risk factor (OPROF)

$\xi_{\mathrm{i}}$ : The coefficient loading for investor sentiment (SENT)

$\gamma_{\mathrm{i}}$ : The coefficient loading for the interaction between Profitability and sentiment (OPROF*SENT)

$\varphi$ : Speed of adjustment to long-run equilibrium.

ECT: Error Correction Term

$E J, t$ : The random error term capturing other systematic risk factors influencing portfolio returns besides the explanatory variables. The random error term is assumed to be identically and independently distributed of the dependent variable and normally distributed with zero expectation and constant variance $\sigma^{2}$.

Controls: Include the size risk factor (SIZE), value risk factor (VALUE) and asset growth factor (ASTG).

\section{RESULTS AND DISCUSSION}

\section{Profitability Risk Factor and Stock Returns}

Table 1 reports the results of the time-series regression for the mains effects model conducted to establish whether profitability risk factor predicts monthly stock returns on the NSE. The dependent variables in 
this regression were the monthly excess returns on 12 equity portfolios for the nine years (2011-2019). The table illustrates the estimated intercepts, the error correction term and factor loadings. In circumstances where there was at least one lag for an independent variable, a joint F-test of their coefficients was performed to determine their statistical significance.

Table 3a. ARDL Error Correction Regression-Main Effects Model

\begin{tabular}{|l|l|l|l|l|l|l|}
\hline \multicolumn{3}{|l}{ SIZE-INV } & \multicolumn{2}{l|}{ SIZE-B/M } & SIZE-OP \\
\hline & RBA & RBC & RBH & RBL & RBR & RBW \\
\hline RET(-1) & $0.1158^{* *}$ & 0.02415 & 0.0198 & -0.1153 & 0.0385 & 0.0440 \\
\hline MKT & $0.8340^{* *}$ & $0.7808^{* *}$ & $0.9485^{* *}$ & $0.7775^{* *}$ & $0.8524 * *$ & $0.8149^{* *}$ \\
\hline OF & -0.0138 & $-0.1502^{* *}$ & -0.0364 & 0.0059 & 0.0768 & $-0.7887 * *$ \\
\hline Intercept & 0.0035 & 0.0036 & -0.0015 & 0.0058 & 0.0035 & -0.0018 \\
\hline ECT(-1)* & $-0.8842^{* *}$ & $-0.9802^{* *}$ & $-0.9802^{* *}$ & $-1.1153^{* *}$ & $-0.9615^{* *}$ & $-0.9560^{* *}$ \\
\hline Adj. R & 0.7515 & 0.7013 & 0.7292 & 0.7950 & 0.8447 & 0.6368 \\
\hline SE & 0.0259 & 0.0254 & 0.0288 & 0.0204 & 0.0180 & 0.0448 \\
\hline F-stat. & 41.0634 & 32.1160 & 41.7839 & 46.6811 & 83.3937 & 27.5442 \\
\hline $\operatorname{Pr}$ (F-stat) & 0.0000 & 0.0000 & 0.0000 & 0.0000 & 0.0000 & 0.0000 \\
\hline D-W stat. & 2.0817 & 1.9059 & 2.0569 & 2.1077 & 2.0885 & 1.7715 \\
\hline
\end{tabular}

Table 3b. ARDL Error Correction Regression-Main Effects Model (cont..)

\begin{tabular}{|l|l|l|l|l|l|l|}
\hline & \multicolumn{5}{|l|}{ SIZE-INV } & \multicolumn{3}{l|}{ SIZE-B/M } & \multicolumn{2}{l|}{ SIZE-OP } \\
\hline & RSA & RSC & RUSH & RSL & RSR & RSW \\
\hline EX-RET(-1) & -0.0251 & 0.0980 & 0.0583 & $0.2173^{* *}$ & 0.0414 & $0.1626^{* *}$ \\
\hline MKT & $0.6085^{* *}$ & $0.8577^{* *}$ & $0.7549^{* *}$ & $0.7234^{* *}$ & $0.8023^{* *}$ & $0.79601^{* *}$ \\
\hline OF & $-0.2359^{* *}$ & $-0.2292^{* *}$ & $-0.1934^{* *}$ & $-0.2660^{* *}$ & $0.5613^{* *}$ & $-0.3769^{* *}$ \\
\hline Intercept & 0.0009 & 0.0023 & 0.0029 & 0.0047 & -0.0080 & -0.0059 \\
\hline ECT(-1)* & $-1.0251^{* *}$ & $-0.9020^{* *}$ & $-0.9324 * *$ & $-0.7827 * *$ & $-0.9586^{* *}$ & $-0.8374 * *$ \\
\hline & & & & & & \\
\hline Adj. R ${ }^{2}$ & 0.5647 & 0.7523 & 0.7025 & 0.5861 & 0.5850 & 0.8106 \\
\hline SE & 0.0317 & 0.0268 & 0.0257 & 0.0337 & 0.0445 & 0.0224 \\
\hline F-stat. & 20.6428 & 36.7666 & 0.0000 & 13.2718 & 22.3460 & 65.8232 \\
\hline Prob(F-stat) & 0.0000 & 0.0000 & 0.0000 & 0.0000 & 0.0000 & 0.0000 \\
\hline D-W stat. & 2.1249 & 2.1702 & 2.0599 & 1.8885 & 1.9188 & 1.7163 \\
\hline
\end{tabular}

Source: Author's own calculations in Eviews 10

**Denotes variable is significant at $5 \%$ level

Tables $3 \mathrm{a}$ and $3 \mathrm{~b}$ display results of ARDL regression conducted to test the null hypothesis of no significant effect of the profitability risk factor on stock returns at the NSE. It is noticeable that when portfolios sorted on size and profitability are considered, robust portfolios RBR $(r=0.0768, p$-value $=$ $0.1337)$ and RSR $(r=0.5613, p$-value $=0.0000)$ have largest coefficients while weak portfolios RBW $(r=-0.7887, p$-value $=0.0000)$ and RSW $(r=-0.3769, p$-value $=0.0000)$ have least coefficients. The same result was consistent with Mosoeu and Kodongo (2015) in South Africa and Novy-Marx (2013) in the US. It is also observed that nine (9) portfolios have negative loadings on the profitability factor. This implies that the higher the operating profitability premium, the lower the stock excess returns. Overall, the profitability factor was statistically significant at a 5\% level in eight (8) out of twelve (12) test portfolios, six (6) of which were small-sized. Therefore, it was concluded that the profitability risk factor has a negative statistically significant effect on stock excess returns at the NSE. These findings, 
however, contrast with fundamental valuation postulations and empirical evidence by Faff (2004), who did not find pricing effect of profitability in the Brazilian market and Ngumi and Njogo (2017), who observed a weak but positive profitability effect in Kenya.

\section{Investor Sentiment, Profitability Risk and Stock Returns}

Tables $4 \mathrm{a}$ and $4 \mathrm{~b}$ display the ARDL time-series regression results performed to establish the effect of sentiment variable in the relationship between profitability risk and stock returns at the NSE on each set of the 12 portfolios. The regressors in the interaction model comprise the lagged value of excess portfolio returns, the market, profitability, sentiment and the interaction between profitability and sentiment. It was conceptualized that the influence of sentiment could either be direct or through interaction, controlling for market risk, size, value and asset growth factor. The multivariate regression model representation is as shown in the figure below.

$$
\begin{aligned}
& \Delta\left(R_{j}-r_{f}\right)_{t}=\alpha_{0}+\delta_{\mathrm{i}} \Delta\left(R_{j}-r_{f}\right)_{t-i}+\beta_{\mathrm{i}} \Delta(M K T)_{t-i}+s_{\mathrm{i}} \Delta(O P R O F)_{t-i}+ \\
& \xi_{\mathrm{i}} \Delta(S E N T)_{t-i}+\gamma_{\mathrm{i}} \Delta(O P R O F * S E N T)_{t-i}+\operatorname{CONTROLS~}_{t-i}+\varphi E C T_{t-1}+e_{4 t}
\end{aligned}
$$

The sentiment effect was established by assessing the change in adjusted $R^{2}$ and significance of the sentiment variable and its interaction with profitability risk factor in the interaction model.

Table 4a. ARDL Error Correction Regression-Interaction Model

\begin{tabular}{|l|l|l|l|l|l|l|}
\hline \multicolumn{2}{|l}{} & \multicolumn{2}{l|}{ SIZE-INV } & \multicolumn{2}{l|}{ SIZE-B/M } & \multicolumn{2}{l|}{ SIZE-OP } \\
\hline Variable & RBA & RBC & RBH & RBL & RBR & RBW \\
\hline EX-RET(-1) & $0.0794^{* *}$ & $0.1578^{* *}$ & 0.0184 & 0.0098 & 0.0373 & 0.0934 \\
\hline MKT & $0.6907^{* *}$ & $0.5329^{* *}$ & $0.9396^{* *}$ & $0.5556^{* *}$ & $0.7238^{* *}$ & $0.6651^{* *}$ \\
\hline OF & -0.0141 & 0.0987 & -0.0360 & 0.0286 & $0.0968^{* *}$ & $-0.7730^{* *}$ \\
\hline SENT & $0.0183^{* *}$ & $-0.0222^{* *}$ & 0.0002 & $0.0270^{* *}$ & 0.0156 & 0.0167 \\
\hline OPROF*SENT & $0.2173^{* *}$ & 0.0439 & 0.0809 & 0.0917 & -0.0082 & $-0.0235^{* *}$ \\
\hline Intercept & 0.0074 & 0.0065 & -0.0019 & $0.0108^{* *}$ & 0.0069 & $0.5823^{* *}$ \\
\hline ECT(-1)* & $-0.9212^{* *}$ & $-0.8422^{* *}$ & $-0.9816^{* *}$ & $-0.9902^{* *}$ & $-0.9627^{* *}$ & $-0.9066^{* *}$ \\
\hline Adj. R $^{*}$ & 0.7645 & 0.7200 & 0.7245 & 0.8113 & 0.8517 & 0.6565 \\
\hline SE & 0.0252 & 0.0246 & 0.0290 & 0.0195 & 0.0175 & 0.0436 \\
\hline F-stat. & 39.2321 & 28.2555 & 31.9672 & 51.6340 & 68.6523 & 21.2583 \\
\hline Prob(F-stat) & 0.0000 & 0.0000 & 0.0000 & 0.0000 & 0.0000 & 0.0000 \\
\hline D-W stat. & 2.0277 & 2.0626 & 2.0396 & 2.2392 & 1.9737 & 1.8781 \\
\hline
\end{tabular}

Table 4b. ARDL Error Correction Regression-Interaction Model (cont.)

\begin{tabular}{|l|l|l|l|l|l|l|}
\hline \multicolumn{3}{|l|}{} & \multicolumn{2}{l|}{ SIZE-INV } & SIZE-B/M & \multicolumn{2}{l|}{ SIZE-OP } \\
\hline Variable & RSA & RSC & RUSH & RSL & RSR & RSW \\
\hline EX-RET(-1) & 0.0345 & 0.0713 & 0.0739 & $0.2128^{* *}$ & 0.0297 & 0.0452 \\
\hline MKT & $0.3880^{* *}$ & $0.6957^{* *}$ & $0.5003^{* *}$ & $0.6520^{* *}$ & $0.5963^{* *}$ & $0.4468^{* *}$ \\
\hline OF & $-0.1906^{* *}$ & $-0.2102^{* *}$ & $-0.2132^{* *}$ & $-0.2202^{* *}$ & $0.5965^{* *}$ & $-0.3230^{* *}$ \\
\hline SENT & $0.0282^{* *}$ & $0.0253^{* *}$ & $0.0309^{* *}$ & 0.0122 & 0.0242 & $0.0456^{* *}$ \\
\hline OPROF*SENT & 0.1084 & & 0.1778 & 0.0040 & 0.0877 & -0.1919 \\
\hline Intercept & 0.0032 & -0.0007 & 0.0094 & 0.0033 & -0.0050 & $0.0062^{* *}$ \\
\hline ECT(-1)* & $-0.9655^{* *}$ & $-0.9309^{* *}$ & $-0.9261^{* *}$ & $-0.7764^{* *}$ & $-0.9703^{* *}$ & $-0.9548^{* *}$ \\
\hline Adj. $\mathrm{R}^{\wedge} 2$ & 0.5752 & 0.7795 & 0.7454 & 0.5765 & 0.5933 & 0.8576 \\
\hline SE & 0.0314 & 0.0252 & 0.0237 & 0.0341 & 0.0441 & 0.0194 \\
\hline
\end{tabular}




\begin{tabular}{|l|l|l|l|l|l|l|}
\hline F-stat. & 15.3515 & 32.2236 & 24.8720 & 14.1198 & 20.3253 & 80.7819 \\
\hline Prob(F-stat) & 0.0000 & 0.0000 & 0.0000 & 0.0000 & 0.0000 & 0.0000 \\
\hline D-W stat. & 2.1105 & 1.9176 & 2.0346 & 1.8665 & 1.8655 & 1.8314 \\
\hline
\end{tabular}

Source: Author's own calculations in Eviews 10

**Denotes variable significant at $5 \%$ level

Results in Table $4 \mathrm{a}$ and $4 \mathrm{~b}$ show that 8 out of 12 (66.67\%) regressions had significant coefficients on profitability risk factor in the interaction model, higher than the $58 \%$ reported in the main effects model. This result suggests that by augmenting the FF5F model with the SENT variable, the predictive significance of the profitability variable is enhanced. In 8 out of the 12 test portfolios, the profitability risk factor had negative coefficients, implying that a high operating profitability premium would lower stock returns. All coefficients of the variable SENT were positive in all portfolios except for large conservative investment portfolios $(s e e=-0.0222, p$-value $=0.0067)$. This implies that a unit increase in the bull-bear spread would increase required returns on the investment portfolio of stocks by the respective factor loadings except on $\mathrm{RBC}$, whose returns would decrease. It is also observed that the sentiment variable had significant coefficients in $58 \%$ of the regressions. The coefficients of the interaction term (OPROF*SENT) were not significant across 10 portfolios except RBA $(i=0.2173, p$ value $=0.0433)$ and RBW $(i=-0.0235, p$-value $=0.0450)$. The non-significant coefficients of the interaction term OPROF*SENT are interpreted to mean that the effect of profitability risk on stock returns does not depend on the level of investor sentiment in the market. Similarly, the effect of the sentiment variable on stock returns does not depend on exposure level to profitability risk. Since then (10) in twelve (12) interaction terms had insignificant coefficients and 58\% of the portfolios had significant loading on the SENT variable, it suffices to conclude that the two variables (OPROF and SENT) are independent and that investor sentiment has a direct influence on stock under the FF5F model framework at the NSE.

\section{Main Effects Model Performance}

The intercept value represents the abnormal return that cannot be explained by the factors included in the model. The $p$-values of the intercepts in the main effects model are greater than 5\%, suggesting that intercepts of the regressions are not significantly different from zero. Hence, the regressors are good proxies for systematic risk. The mean adjusted R-square for the main effects model implies that the model without interaction accounts for $70.73 \%$ variation in the stock returns at NSE. The probability values of F-statistics are very small (less than 5\%), suggesting that the overall model in each portfolio regression is significant. The ECT is negative and significant in all error correction regressions. The negative coefficient on ECT signifies evidence of long-run convergence/reversion to equilibrium, and thus we can infer a long-run causal relationship.

\section{Interaction Model Performance}

The lower panel of Tables $4 \mathrm{a}$ and $4 \mathrm{~b}$ show statistics for the model performance of the interaction model involving investor sentiment and operating profitability risk factors. The null hypothesis of $\alpha=0$ is supported in 9 out of 12 regressions but rejected on size-B/M sorted portfolios, namely RBL $(\propto=$ $0.0108, p$-value $=0.0409), \mathrm{RBW}(\propto=0.5823, p$-value $=0.0145)$ and RSW $(\propto=0.0062, p$-value $=$ 0.0011). This implies that the models completely capture the cross-section of returns efficiently. By comparing the estimates of adjusted R-square for the main effects and interaction model, it is observed that the addition of SENT and interaction variable to the main effects model increases the explanatory power of the model marginally by raising the mean adjusted R-square to $72.13 \%$. This implies that the added factors are efficient and better explain stock returns. The probability values of F-statistics are very small (less than 5\%), suggesting that the overall model in each portfolio regression is significant. The ECT is negative and significant in all error correction regressions ranging from the lowest $(\mathrm{ECT}(-1)=$ $-0.7764, p$-value $=0.0000)$ on RSL to the highest $($ ECT $(-1)=-0.9902, p$-value $=0.0000)$ on RBL 
portfolio. The negative coefficient on ECT implies that there is evidence of long-run convergence/reversion to equilibrium in that particular regression. Thus we can infer a long-run causal relationship. The reversion to long-run equilibrium is at an adjustment speed of $77.64 \%$ and $99.02 \%$ on the RSL and RBL portfolios, respectively.

\section{CONCLUSION}

This study sought to establish if the profitability risk factor explains stock returns at the NSE. The analysis concluded that the profitability factor is a strong predictor of stock returns at the NSE, controlling for other factors in the FF5F model framework. A high profitability risk premium lowers the stock excess returns consistent with Novy-Marx (2013). The result, however, does not corroborate the postulation in valuation theory which suggests that firms with higher profitability have higher expected returns. Therefore, it is implied that investors at the NSE do not perceive high profitable firms as risky. Hence, investment strategies based on profitability may not yield higher returns on average.

Further, the addition of sentiment variables to the main effects model enhances the significance of the profitability risk factor. Overall, this study concludes that the effect of profitability risk factors and investor sentiment on excess returns are independent. The study recommends a model that incorporates investor sentiment as a proxy for systematic risk in the investment decisions by market players in Kenya.

\section{AUTHOR CONTRIBUTIONS}

Conceptualization: Nebat G. Mugenda, Tobias Olweny, Joshua M. Wepukhulu

Data Curation: Nebat G. Mugenda

Formal Analysis: Nebat G. Mugenda

Funding Acquisition: Nebat G. Mugenda, Tobias Olweny, Joshua M. Wepukhulu

Investigation: Nebat G. Mugenda, Tobias Olweny, Joshua M. Wepukhulu

Methodology: Nebat G. Mugenda, Tobias Olweny, Joshua M. Wepukhulu

Project Administration: Nebat G. Mugenda, Tobias Olweny, Joshua M. Wepukhulu

Resources: Nebat G. Mugenda, Tobias Olweny, Joshua M. Wepukhulu

Software: Nebat G. Mugenda

Supervision: Tobias Olweny, Joshua M. Wepukhulu

Validation: Nebat G. Mugenda, Tobias Olweny, Joshua M. Wepukhulu

Visualization: Nebat G. Mugenda, Tobias Olweny, Joshua M. Wepukhulu

Writing - Original Draft: Nebat G. Mugenda

Writing - Review \& Editing: Nebat G. Mugenda, Tobias Olweny, Joshua M. Wepukhulu

\section{CONFLICT OF INTEREST STATEMENT}

The authors declare that they have no competing interests.

\section{ACKNOWLEDGEMENT}

All authors contributed equally to the conception and design of the study.

\section{REFERENCES}

Aharoni, G., Grundy, B., \& Zeng, Q. (2013). Stock returns and the Miller Modigliani Valuation Formula: Revisiting the Fama French Analysis. Journal of Financial Economics, 110(2), 347-357. Retrieved from https://ideas.repec.org/a/eee/jfinec/v110y2013i2p347-357.html 
Ayrapetova, T \& Larionova, K. (2016). The Cost of Equity in Emerging Markets: A Downside Risk Approach. $\quad$ Retrieved from https://Faculty.Fuqua.Duke.Edu/ Charvey/Teaching/Ba456_2001/Estrada.Pdf

Baker, M., \& Wurgler, J. (2006). Investor sentiment and the cross-section of stock returns. The journal of Finance, 61(4), 1645-1680. Retrieved from https://afajof.org/journal-of-finance.

Baker, M., \& Stein, J. C. (2004). Market liquidity as a sentiment indicator. Journal of Financial Markets, 7(3), 271-299. Retrieved from https://www.journals.elsevier.com/journal-of-financial-markets

Basiewicz, P. G., \& Auret, C. J. (2010). Feasibility of the Fama and French three factor model in explaining returns on the JSE. Investment Analysts Journal, 39(71), 13-25. Retrieved from https://www.tandfonline.com/toc/riaj20/current

Bathia, D., \& Bredin, D. (2013). An examination of investor sentiment effect on G7 stock market returns. The European Journal of Finance, 19(9), 909-937. Retrieved from https://afajof.org/journal-offinance.

Berk, J. B., \& Van Binsbergen, J. H. (2016). Assessing asset pricing models using revealed preference. Journal of Financial Economics, 119(1), 1-23.

Brown, G. W., \& Cliff, M. T. (2005). Investor sentiment and asset valuation. The Journal of Business, $78(2), 405-440$.

Chae, J., \& Yang, C. (2016). Why do Some Asset Pricing Models Perform Poorly? Evidence from Irrationality, Transaction Costs, and Missing Factors. Seoul Journal of Business, 22(1), 1-64.

Chen, L., Novy-Marx, R., \& Zhang, L. (2011). An alternative three-factor model. Available at SSRN 1418117.

Chuang, W. J., Ouyang, L. Y., \& Lo, W. C. (2010). The impact of investor sentiment on excess returns: A Taiwan stock market case. International Journal of Information and Management Sciences, 21(1), 13-28. Retrieved from https://www.researchgate.net/publication/229012474

Coffie, W., \& Chukwulobelu, O. (2013). The Cost of Equity Capital in Emerging Markets - The Case of Kenya. GSTF Journal on Business Review (GBR), 2(4), 192-199.

Dalika, N., \& Seetharam, Y. (2015). Sentiment and Returns: an Analysis of Investor Sentiment in the South African market. Investment Management and Financial Innovations, 12(1-2), 267-276.

Dash, S.R., \& Mahakud, J. (2013). Impact of Investor Sentiment on Stock Return: Evidence from India, Journal of Management Research, 13(3), 131-14.

Faff, R. (2004). A simple test of the Fama and French model using daily data: Australian evidence. Applied Financial Economics, 14(2), 83-92.

Fama, E. F., \& French, K. R. (2006). The Capital Asset Pricing Model: Theory and Evidence. Journal of Economic Perspectives, 18(3), 25-46.

Fama, E. F., \& French, K. R. (2015). A Five-Factor Asset Pricing Model. Journal of Financial Economics, 116(1), 1-22. 
Fama, E. F., \& French, K.R. (1992). The Cross-Section of Expected Stock Returns. The Journal of Finance, 47(2), 427-465.

Fama, E.F., \& French, K. R. (1993). Common Risk Factors in the Returns on Stocks and Bonds, Journal of Financial Economics, 33, 3-56.

Gujarati, N.D. (2003). Basic Econometrics (4th Edition), New York: Mcgraw Hill.

Hiremath, G.S. (2014). Indian Stock Market: An Empirical Analysis of Informational Efficiency, Springer Briefs in Economics, Springer

Hearn, B., \& Piesse, J. (2009). Sector level cost of equity in African financial markets. Emerging Markets Review, 10(4), 257-278.

Karp, A., \& Vuuren, G. (2017). The Capital Asset Pricing Model and Fama-French Three Factor Model in an Emerging Market Environment. International Business \& Economics Research Journal, 16(3), 231-256.

Kubota, K., \& Takehara, H. (2018). Does the Fama and French five-factor model work well in Japan?. International Review of Finance, 18(1), 137-146.

Li, D., \& Zhang, L. (2010). Does q-theory with investment frictions explain anomalies in the crosssection of returns?. Journal of Financial Economics, 98(2), 297-314.

Lind, J., \& Sparre, L. (2016). Investigating New Multifactor Models with Conditional Beta, Journal of Business and Economics, 26(2), 22-29.

Mosoeu, S., \& Kodongo, O. (2017). Testing the Fama-French Five-Factor Model in selected Emerging and Developed Markets. Emerging Markets Review, 133-155

Narayan, P.K. (2005). The saving and investment nexus for China: evidence from co-integration tests. Appl. Econ. 37, 1979-1990.

Nguyen, D. M. (2016). Fama-French Five-factor model: Evidence from Viet Nam. Retrieved from https://osuva.uwasa.fi/handle/10024/3480

Novy-Marx, R. (2013). The Other Side of Value: The Gross Profitability Premium. Journal of Financial Economics, 8(1), 1-28.

Ngumi, D. K., \& Njogo, M. M. (2017). Effect of budgeting practices on the financial performance of insurance companies in Kenya. International Journal of Economics, 2(3), 14-30.

Pesaran, M. H., Shin, Y., \& Smith, R. J. (2001). Bounds testing approaches to the analysis of level relationships. Journal of applied econometrics, 16(3), 289-326.

Schmeling, M. (2009). Investor sentiment and stock returns: Some international evidence. Journal of empirical finance, 16(3), 394-408.

Taha, R., \& Elgiziry, K. (2016). A Five-Factor Asset Pricing Model: Empirical Evidence from Egypt. International Journal of Business, 21(4), 1083-4346. 
Tran, T., \& Nguyen, N. (2013). The effect of Investor Sentiment on Stock Returns. Retrieved from http://www.cbsnews.com/8301-505123_162-57458690

\section{Copyrights}

Copyright for this article is retained by the author(s), with first publication rights granted to the journal. This is an open-access article distributed under the terms and conditions of the Creative Commons Attribution license (https://creativecommons.org/licenses/by/4.0). 